\title{
La rappresentazione digitale per la documentazione e l'investigazione: il caso studio del monumento garibaldino ai Ponti della Valle
}

Domenico lovane

Rosina laderosa

\section{Abstract}

La ricerca condotta sul monumento Ossario ai caduti nella battaglia del $1^{\circ}$ ottobre 1860 presso $\mathrm{i}$ Ponti della Valle, si pone l'obiettivo di indagare il caso studio tramite un approccio multidisciplinare, per conoscere e completare le mancanze che con una sola chiave di lettura si presenterebbero. II monumento, infatti, una volta noto e fruito è caduto da alcuni decenni in oblio e la sua narrazione documentaria/archivistica si presenta scarna di fonti grafiche. Pertanto, all'interno di un processo cognitivo, caratterizzato da una vasta gamma di fonti, si è deciso di utilizzare il rilievo quale processo metodologico volto alla conoscenza, documentazione, valorizzazione e comunicazione del bene realizzando modelli tridimensionali fotorealistici ed immagini equirettangolari navigabili in remoto.

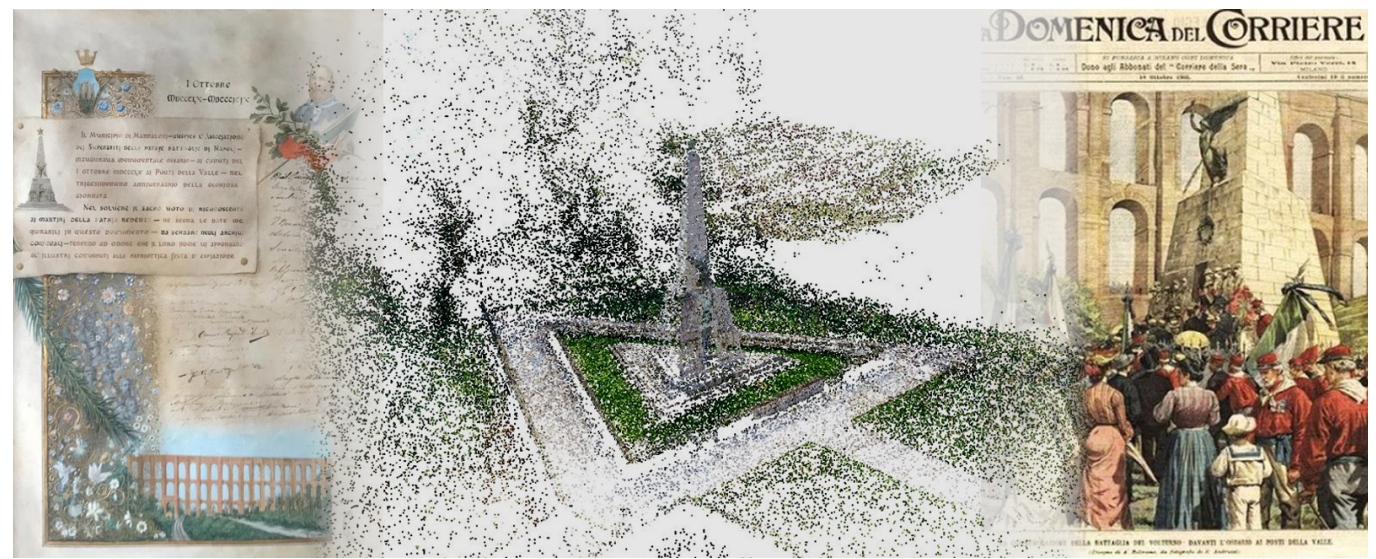




\section{II racconto storico del costruito attraverso ricerche documentali inedite}

Ogni luogo della memoria è il prodotto degli eventi che lo vedono coinvolto nel tempo. Per questo, quasi certamente, un solo luogo della memoria accoglie più di una storia, spesso una in antitesi di un'altra, proprio come i Ponti della Valle. Essi, infatti, nacquero dal sogno di magnificenza di un re e diventarono simbolo di potenza di un'intera dinastia per poi cento anni dopo trasformarsi nel teatro del disfatto della stessa. Era il $I^{\circ}$ ottobre 1860 , quando presso l'acquedotto Carolino si svolse lo scontro decisivo della battaglia campale considerata, dai più, simbolo dell'intero Risorgimento, la battaglia del Volturno. Seppur il nome rievoca il fiume Volturno esso non fu protagonista delle vicende, che si svolsero invece nell'entroterra casertano, tra i territori di Santa Maria Capua Vetere, Sant'Angelo in Formis e le pendici dei monti Tifatini.

Tra i comuni di Maddaloni eValle di Maddaloni si schierarono le truppe del garibaldino Bixio, che stabili il suo quartier generale nella Villa Gualtieri, e le brigate borboniche del generale Von Meckel, che si staccarono, prima dell'alba del $1^{\circ}$ ottobre |860, da quelle del generale Ruiz con cui stavano presso Limatola. In seguito a più riprese di attacchi e scontri ebbero la meglio i garibaldini, che provocarono la ritirata delle truppe borboniche ed il conseguente scoraggiamento delle stesse che determinò la resa finale e la vittoria definitiva di Garibaldi. Le vicende storiche influirono sul riassetto societario, tanto che stesso il popolo, in precedenza largamente a favore dei sovrani borbonici, chiedeva di organizzare eventi a favore del ricordo della battaglia e collocare moniti. L'idea di erigere un monumento ai Ponti della Valle che raccogliesse le ossa dei caduti il $1^{\circ}$ ottobre 1860 fu del presidente dell'Associazione dei Superstiti delle patrie battaglie di Napoli,Vincenzo Migliorini.Tramite una nota scritta, datata 7 settembre 1887, rese partecipe di quest'idea il sindaco di Maddaloni Giuseppe Tammaro, che accolse benevolmente la proposta, tanto che concesse il patrocinio attivo del comune ed in breve tempo venne costituito un comitato promotore per la realizzazione del monumento. Tra i vari compiti del comitato vi era quello di raccogliere i fondi necessari alla realizzazione. A tal proposito, in poco arrivarono aiuti monetari da amministrazioni comunali e privati, nonché da sua maestà il re.

Gli studi archivistici condotti hanno portato come frutto solo documenti scritti, che narrano il progetto del monumento e le sue variazioni, e nessun documento grafico. Nel documento [ I] datato 25 maggio 1888, si riporta che il progetto era a firma dell'ing. cav. Carmelo Destino e dello scultore prof. Enrico Mossuti e che "il monumento sorgerà sulle pendici a destra dei Ponti della Valle venendo da Maddaloni". Inoltre, esso "avrà una base di pietra travertino su scaloni. [...] Nel basamento di pietra travertino saranno scolpite a grande rilievo le figure principali di garibaldini. Sarà sormontata da un gruppo di tre faci bronzate rovesciate legati da rami di quercia e nastri. Queste faci a loro volta saranno sormontate dalla stella d'Italia

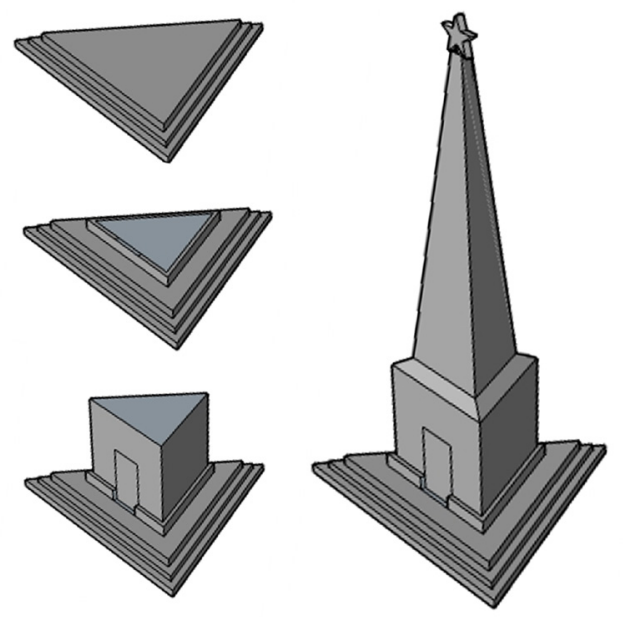


in metallo brillante. In giro ai gradoni saranno sparsi avanzi d'arme. [...] La parte del basamento ha nel d'avanti un vano fregiato [...] che da l'accesso all'interno, che sarà l'ossario. Tutto il monumento figurerà una piramide triangolare posta su tre scaloni. Ultimato il lavoro è necessario di cingere il monumento con alberi d'alto fusto per limitarne l'orizzonte".

Nel documento si fa riferimento ad un bozzetto, che avrebbe dovuto riportare anche le dimensioni dei singoli elementi. II bozzetto non è presente negli archivi però dalla descrizione è stato possibile conoscere le misure dei suddetti elementi "il primo scalone lungo $\mathrm{m}$. I0, I0 per ogni lato; il secondo m. 3,50; il terzo m. 8,90 ed ognuno d'altezza 0,33 m. e per 0,30 di pedata [...]. Sulla zoccolatura accennata sorge il tronco di piramide di larghezza per ogni lato di m. 5,50 in base e m. 3,70 in cima. L'altezza è di m. 4,50 [...] Sormonta la piramide le tre faci sormontate dalla stella d'Italia, della complessiva altezza di m. I I,00".

La spesa necessaria per l'esecuzione del monumento era stimata a circa quindicimila lire. Dalla scrittura pubblica [2] si evince che "i suddetti signori [...] convennero l'esecuzione del detto progetto sotto la direzione dell'ingegnere Cav. Carmelo Destino". Inoltre, fu stabilito che "il monumento doveva essere completato e conseguito per tutto il mese di settembre del seguente anno I89|".

Per varie difficoltà che si succedettero non fu possibile tale cosa, e per questo dal documento si evince che "dovendosi ora menare a termine il lavoro il Mossuti ha con l'annuenza del comitato, affidato al signor Giuseppe Cozzolino l'esecuzione dell'opera in muratura e pietra calcare".

Tra i motivi che determinarono il ritardo vi fu la compravendita del terreno demaniale su cui erigere il monumento [3], che avvenne il giorno I I agosto | 899, e le variazioni al progetto con lavori non considerati nella stima iniziale. Tra questi: sbancamento e trasporto del terreno non utilizzabile; fondazione per raggiungere gli 8,50 m. e scelta di fare la cripta ad arco di scarico in mattoni.

In conclusione, nel documento 6 - 224 è scritto "I'Ingegnere Direttore e collaudatore, esaminato il Monumento [...] certifica che i lavori sono, non solo collaudabili, ma anche sotto ogni rapporto commendevoli" [4].

Così il $1^{\circ}$ ottobre 1899 , nell'anniversario della battaglia, fu inaugurato con una significativa parata il monumento garibaldino.

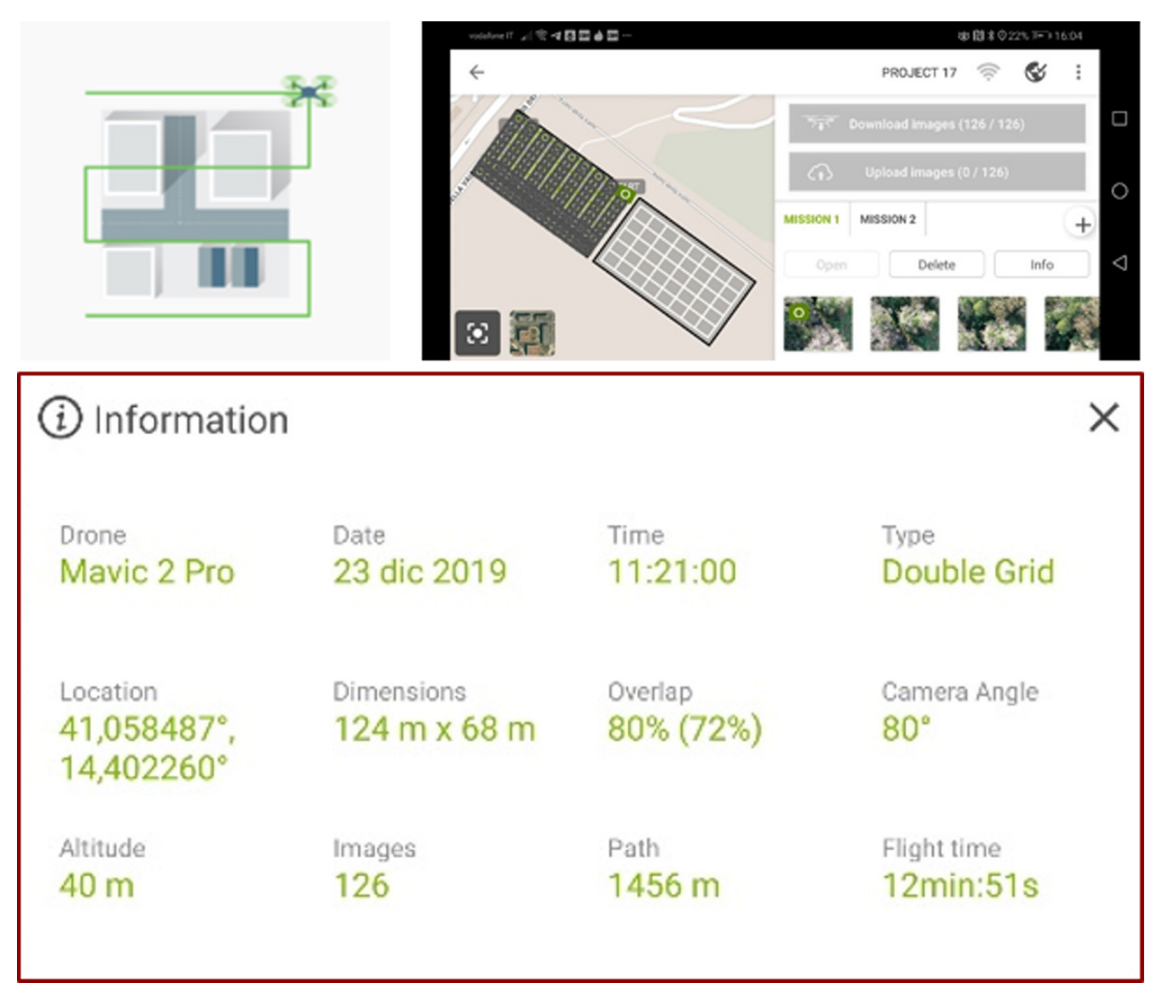




\section{La conoscenza attraverso la fruizione del modello digitale}

Le varie metodologie utilizzate hanno definito le diverse fasi operative finalizzate alla realizzazione di modelli digitali tridimensionali volti alla documentazione, fruizione e comunicazione del monumento garibaldino. Da quanto si evince in precedenza, le attività di ricerca storica documentaria, svolte presso varie strutture (Biblioteca Soprintendenza sede Caserta, Archivio di Stato Caserta, Biblioteca Comune Maddaloni, Biblioteca Museo Civico Maddaloni), sono state di importanza fondamentale per poterne documentare l'evoluzione. Questo tipo di attività, infatti, è diventato processo cognitivo che tramite le attività complesse del rilievo, diviene strumento di conoscenza per la documentazione, la valorizzazione e la determinazione di moderni metodi di comunicazione.

Le fasi principali dello studio condotto si possono racchiudere in:

- ricerca di archivio di documenti, che ha determinato la conoscenza e le trasformazioni tramite cui è stato possibile ricostruire la storia, a ritroso, del monumento;

- registrazione di dati metrici e architettonici, che ha consentito di determinare una conoscenza diretta del monumento. Le informazioni desunte dalle fasi di rilevamento hanno visto l'utilizzo di tecnologie no-contact, con sensori ottici passivi e basate sull'acquisizione di immagini;

- elaborazione dei dati con determinazione di un modello rappresentativo lo stato dei luoghi e di un modello che ripropone la configurazione originaria del monumento;

- infine, scelta di sistemi di comunicazioni finalizzati alla conoscenza, valorizzazione e divulgazione del sito.

L'articolazione del monumento, legata anche alla conformazione del sito, ha determinato una campagna di acquisizione basata su un progetto di indagine dettagliato, al fine di poter scegliere le migliori soluzioni in termini di tecniche e fasi di acquisizione dei dati metrici. Pertanto, per l'acquisizione di dati metrici e colorimetrici sono state utilizzate tecnologie non invasive e no-contact. La decisione, di effettuare un rilevamento digitale integrato, si è concretizzata in un approccio multi-risoluzione di registrazione dei data set fotografici, con acquisizioni terrestri ed avioriprese, e successive elaborazioni basate su algoritmi fotogrammetrici. I data set fotografici da avioriprese sono stati registrati con drone marca DJl, modello Mavic 2 Pro, con acquisizione di circa duecento immagini. Le immagini sono state acquisite con preventiva pianificazione di volo in modo da garantire l'intera copertura del monumento, parte dell'area esterna e ridurre al minimo il rumore.
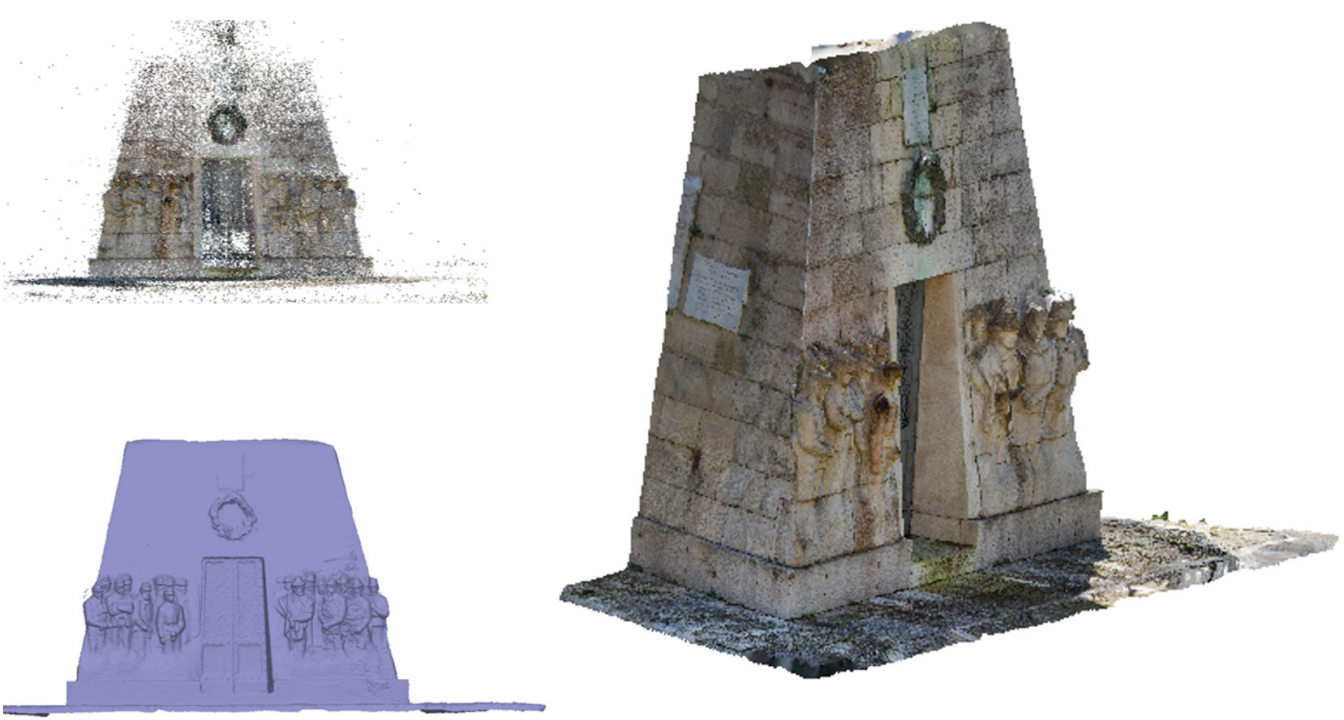
II monumento è stato indagato secondo tre modalità di volo:

- double grid, con area di acquisizione di circa 124m $\times 68 \mathrm{~m}$, doppia griglia ortogonale di volo, overlap dell' $80 \%$, camera inclinata a $80^{\circ}$, altitudine di volo $40 \mathrm{~m}$, fotogrammi totali 126 , percorso di volo $1456 \mathrm{~m}$ e tempo di volo pari $12 \mathrm{~min}$. $5 \mathrm{Isec}$.;

- circular, con area di acquisizione di circa $25 \mathrm{~m} \times 25 \mathrm{~m}$, volo circolare, acquisizione fotogrammi ogni $10^{\circ}$, altitudine di volo $18 \mathrm{~m}$, fotogrammi totali 36 , percorso di volo $49 \mathrm{~m}$ e tempo di volo pari $2 \mathrm{~min}$. IOsec;;

- freeflight, acquisizione dei fotogrammi con drone in posizione parallela alla facciata principale del monumento e scatto secondo strisciate verticali, fotogrammi totali 48, percorso di volo $40 \mathrm{~m}$ e tempo di volo pari $6 \mathrm{~min}$. $37 \mathrm{sec}$.

La fotocamera utilizzata, di serie al Mavic 2 Pro, è una Hasselblad integrata, dotata di sensore CMOS dimensioni da I pollice, risoluzione da 20 megapixel e profondità di colore di I0-bit. La fotocamera è dotata del sistema HNCS, Hasselblad Natural Color Solution, che propone i migliori colori naturali possibili. L'HNCS offre transizioni tonali più uniformi e una qualità di immagine simile a una pellicola, grazie alla sua profondità di colore di 16 bit, rispetto alla maggior parte dei sensori DSLR più piccoli.

La pianificazione e gestione del piano di volo è stata effettuata con l'App Pix4Dcapture installata su dispositivo mobile collegato al radiocomando. Scegliendo le diverse pianificazioni, tra quelle presenti all'interno dell'applicazione, è stato possibile impostare i differenti parametri correlati alla qualità e alla precisione del modello da elaborare. II settaggio dei parametri di mappatura ha interessato la sovrapposizione dell'immagini, l'angolazione della fotocamera e l'altitudine di volo in base alle esigenze del sito. È stato possibile monitorare la missione di volo, in tempo reale, usando la visualizzazione della mappa e della telecamera. Analogamente, anche la mapview ha fornito i dati di telemetria, restituendo informazioni relative all'altitudine di volo e velocità di volo.

Tutte le immagini acquisite sono state controllate in loco direttamente dall'app al fine di evitare rilavorazioni. Invece, i data set fotografici con ripresa terrestre, sono stati acquisiti con fotocamera tipo reflex, marca Nikon, modello D40, con l'acquisizione di circa trecento immagini. La battuta terrestre ha avuto lo scopo di approfondire ed integrare, a quella da avioriprese, la parte dei bassorilievi. La fotocamera utilizzata è una DSLR con sensore APS-C dalle dimensioni di $23.5 \times 15.7 \mathrm{~mm}$, risoluzione da 6.0 megapixels e registrazione dei fotogrammi con ottica fissata a $18 \mathrm{~mm}$, utilizzando obiettivo AF-S DX NIKKOR I8-55mm. I data set fotografici sono stati acquisiti nel pieno rispetto della sovrapposizione dell'immagini, circa $80 \%$, integrando riprese ad assi paralleli e riprese ad assi convergenti in base alle esigenze del sito.

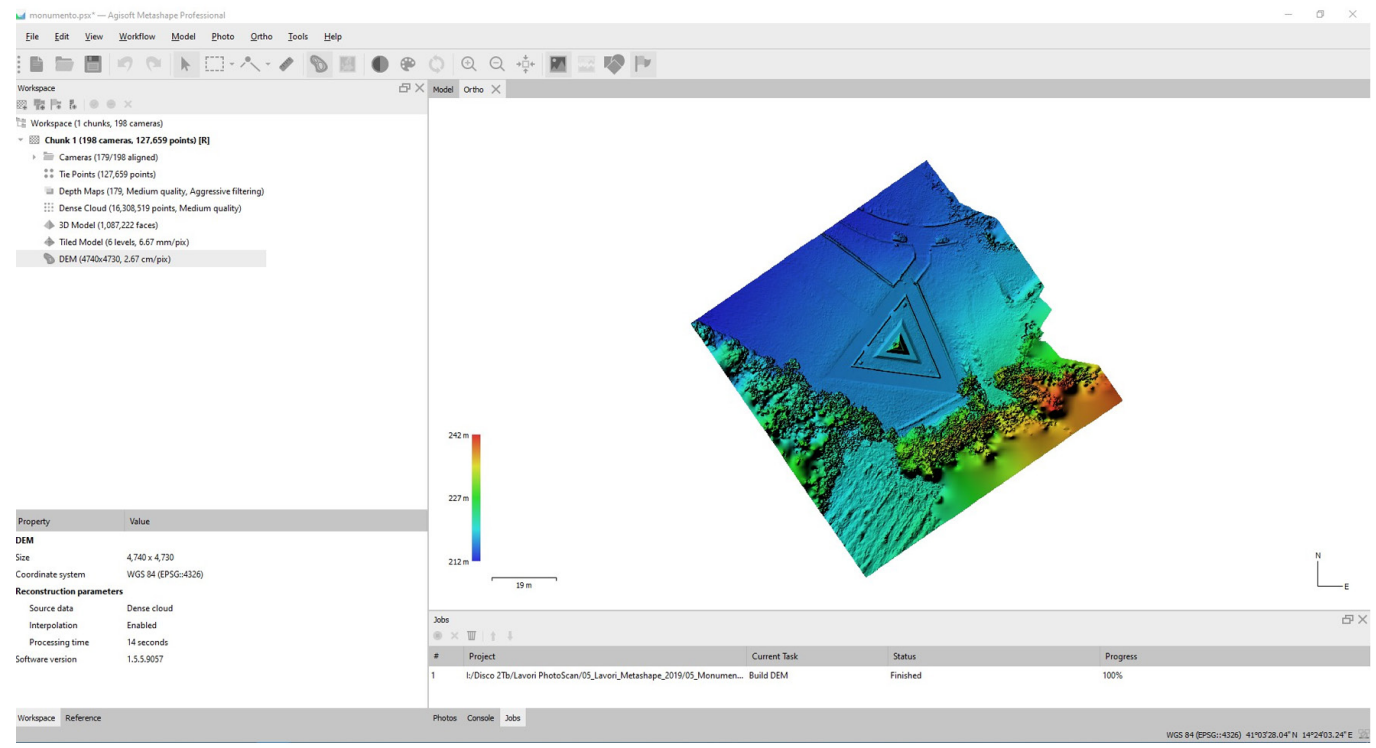


L'elaborazione di tutti i data set fotografici, organizzati per tipologia di acquisizione, è stata effettuata utilizzando il software Agisoft Metashape, basato sull'uso di algoritmi per l'orientamento automatico dei fotogrammi. La nuvola di punti ottenuta, dai dataset fotografici, ha permesso di definire il modello opportunamente scalato in virtù dei dati metrici registrati in sito.

II lavoro ha visto la determinazione di due chunks all'interno del programma che successivamente sono stati uniti e fusi in un unico modello rappresentativo del monumento. Le diverse fasi di acquisizione dei dati fotografici e metrici hanno consentito di poter generare modelli tridimensionali con successiva estrapolazione e determinazione di immagini planari e/o di prospetti consentendo il processo di texturing dei modelli.

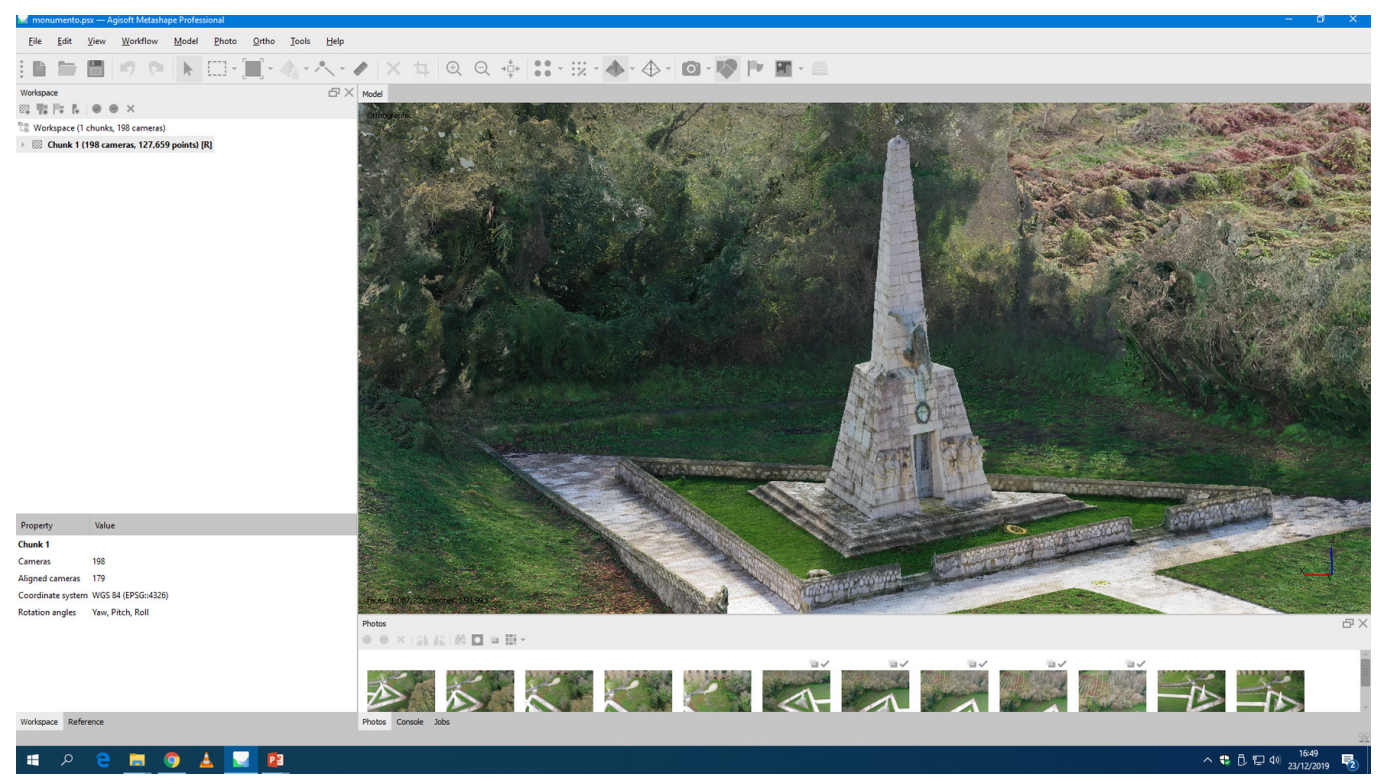

\section{Applicazioni e conclusioni}

Alla generazione di modelli tridimensionali fotorealistici è seguita la fase di valorizzazione e divulgazione del monumento tramite moderni metodi di comunicazione. La possibilità di poter portare in quota una fotocamera, grazie al drone, ha consentito di catturare al meglio, nelle condizioni più disparate, svariate immagini fotografiche, utilizzate in seguito per elaborare immagini equirettangolari. La registrazione dei fotogrammi è stata effettuata con l'App DJI Go 4 installata su dispositivo mobile collegato al radiocomando. II monumento è stato fotografato secondo la modalità di acquisizione pano DJl, in virtù della quale è possibile realizzare una sequenza di scatti grandangolari che in automatico l'applicazione unisce e trasforma in una sola immagine panoramica ad ampia ripresa. Nello specifico sono stati effettuati due voli per un totale di 52 fotogrammi acquisiti, con punto di scatto fisso alle quote di $30 \mathrm{~m}$ e $50 \mathrm{~m}$. La generazione di immagini equirettangolari, caricate su apposite piattaforme di visualizzazione, offre all'utenza una fruizione più realistica del monumento. Il tour virtuale è strumento utilizzato anche e soprattutto per la promozione sul web, la particolare visualizzazione e modalità di navigazione, abbinata a punti di interesse, consente di indagare, a tutto tondo, il patrimonio esistente.

In conclusione, l'approccio multidisciplinare con cui è stato indagato il caso studio ha permesso di restituire nella sua interezza il costruito esistente di un manufatto storico di cui non esistevano rappresentazioni e di cui non si aveva una corretta e valida valorizzazione. L'obiettivo è quello di continuare il lavoro cominciato di documentazione e rappresentazione per diffondere la conoscenza del sito, anche tramite i moderni metodi di comunicazione. 


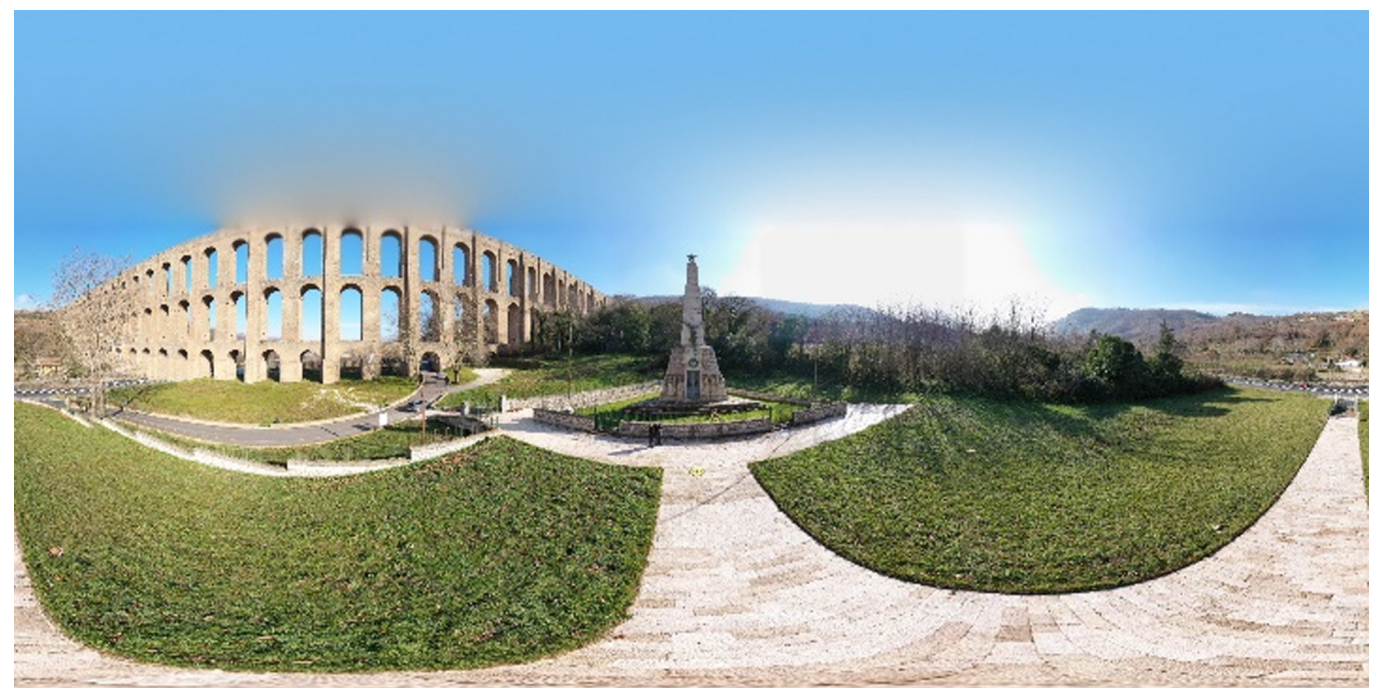

Fig. 7. Immagine quirettangolare, quota $50 \mathrm{~m}$

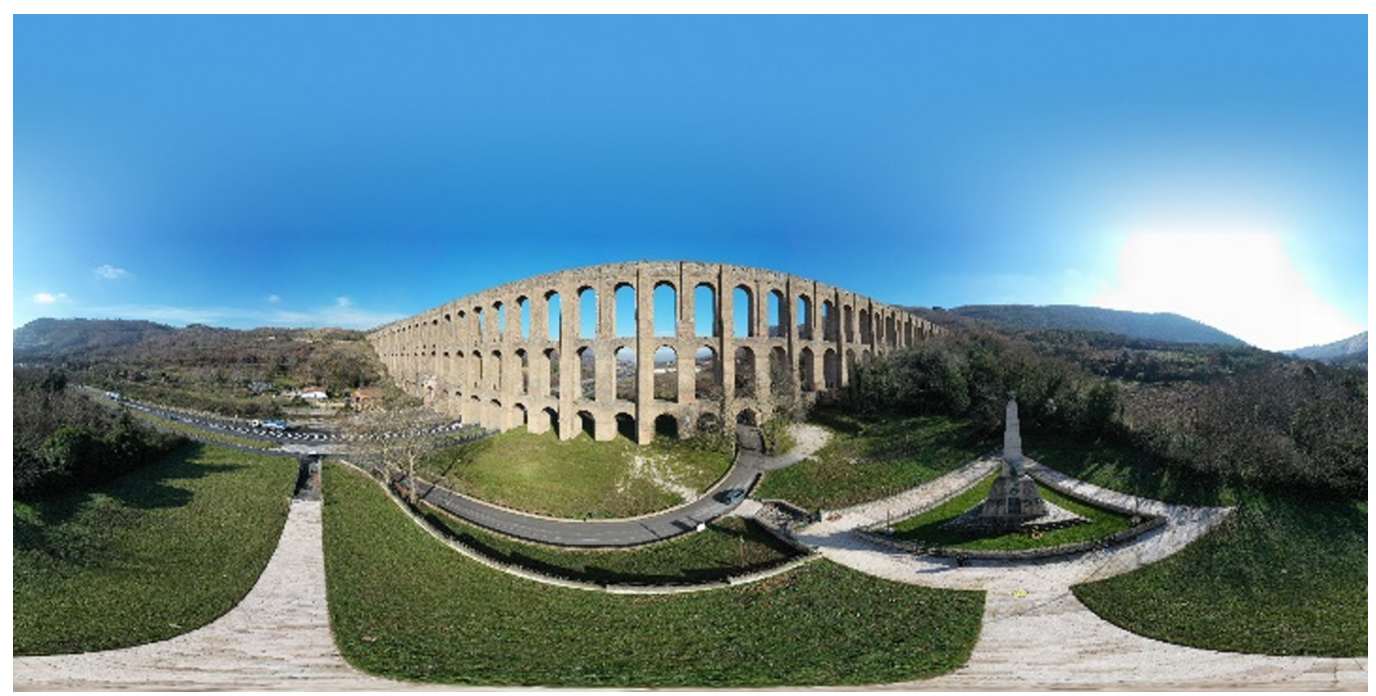


Fig. 8. Tour virtuale: $<$ https://poly.google.com/u/0/ view/eMKI2oWEu8>.

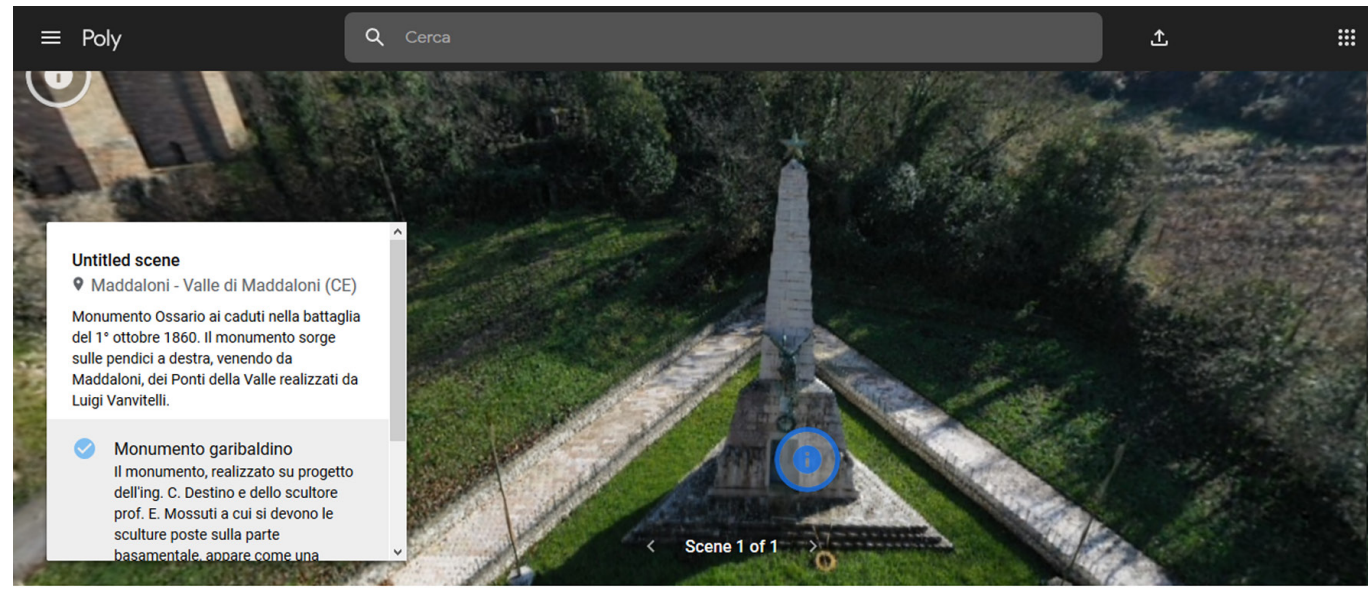

Monumento garibaldino 1 visualizzazione

\section{Note}

[I] A firma del sindaco di Maddaloni G. Tammaro, Archivio Biblioteca Comunale Maddaloni.

[2] Scrittura reg. in Maddaloni il $1^{\circ}$ ottobre seg. al $N^{\circ}$ 139, Archivio Biblioteca Comunale Maddaloni.

[3] Scrittura privata da far valere come atto pubblico, reg. in Maddaloni al Mod. 2,Vol. 19 fl. I 72, Archivio Biblioteca Comunale Maddaloni.

[4] Scrittura pubblica, Archivio Biblioteca Comunale Maddaloni.

\section{Riferimenti bibliografici}

Boriani Lucia, Guidi Maurizio, Toniolo Lucia (2015). Built Heritage: Monitoring Conservation Management. Milano: Springer International Publishing

De Luca Livio (20 I I). La fotomodellazione architettonica. Palermo: Dario Flaccovio Editore, pp I9-29.

Del Pizzo Silvo,Troisi Salvatore (20 I I). Automatic orientation of image sequences in cultural heritage. In ISPRS Ann. Photogramm. Remote Sens. Spatial Inf. Sci., 201 I, XXXVIII-5M I6, pp. 293-300.

Di Lorenzo Giulio (20 I I). Nuove fonti sulla Battaglia del Volturno: elenco delle proposte che si sottomettono all'approvazione del dittatore. In Terra di Lavoro, I-2, 201 I, pp. 74-8I.

Menna Fabio, Erica Nocerino, Remondino Fabio, Saleri Lunazzi Renato (2013). Accuracy and block deformation analysis in automatic UAV and terrestrial photogrammetry - Lesson learnt. In ISPRS Ann. Photogramm. Remote Sens. Spatial Inf. Sci., 20 I3, II-5/WI, pp. 203-208.

Orlandi Marco,Vazzana Antonino, Zambruno Simone (2014). Tecnologia, Beni Culturali e Turismo: i TourVirtuali (Virtual Tours) come strumento per una corretta comunicazione dei Beni Culturali. In Storia e Futuro, 34, 2014.

Orlandi Marco, Vazzana Antonino, Zaccarini Matteo, Zambruno Simone (20l3). Photographing the past: using cloud computing and photo-modelling for 3D historical architecture modelling. In Boriani Maurizio, Gabaglio Rossana, Gulotta Davide. Built Heritage 20 I 3: Monitoring Conservation Management. Milano: Politecnico di Milano, Centro per la Conservazione e Valorizzazione dei Beni Culturali

Pepe Massimiliano, Prezioso Giuseppina (2016). Two Approaches for Dense DSM Generation from Aerial Digital Oblique Camera System. In Proceedings of the 2nd International Conference on Geographical Information Systems Theory, Applications and Management, II, 2016, 10, pp. 63-70

Remondino Fabio (20I I). Rilievo e modellazione 3D di siti e architetture complesse. In Disegnarecon, 8/20 I I, 4, pp. 90-98

\section{Autori}

Domenico lovane, Università degli Studi di Napoli “Federico II", domenico.iovane@unina.it

Rosina laderosa, Università degli Studi di Napoli “Federico II”, rosina.iaderosa92@gmail.com

Per citare questo capitolo: lovane Domenico, laderosa Rosina (2020). La rappresentazione digitale per la documentazione e l'investigazione: il caso studio del monumento garibaldino ai Ponti della Valle/The digital representation for documentation and investigation: the case study of the Garibaldi monument at the Ponti della Valle. In Arena A., Arena M., Brandolino R.G., Colistra D., Ginex G., Mediati D., Nucifora S., Raffa P. (a cura di). Connettere. Un disegno per annodare e tessere. Atti del $42^{\circ}$ Convegno Internazionale dei Docenti delle Discipline della Rappresentazione/Connecting. Drawing for weaving relationships. Proceedings of the 42 th International Conference of Representation Disciplines Teachers. Milano: FrancoAngeli, pp. 2328-2343. 


\section{The Digital Representation for Documentation and Investigation: the Case Study of the Garibaldi Monument at the Ponti della Valle}

Domenico lovane

Rosina laderosa

\section{Abstract}

The research conducted on the Ossuary Monument to the fallen on I October 1860 battle at the Ponti della Valle, aims to investigate the case study through a multidisciplinary approach, in order to know and complete the shortcomings that would present with a single reading key. After that it was known and used, in fact, the monument fell into oblivion for a long time and its documentary / archival narration is lacking in graphic sources. So, within a cognitive process, characterized by a wide range of sources, it was decided to use the survey as a methodological process aimed at knowledge, documentation, enhancement and communication of the asset. Therefore, photorealistic three-dimensional models and equirectangular images navigable remotely were realizing.

Keywords

archival documentation, survey, 3D digital representations, virtualization.

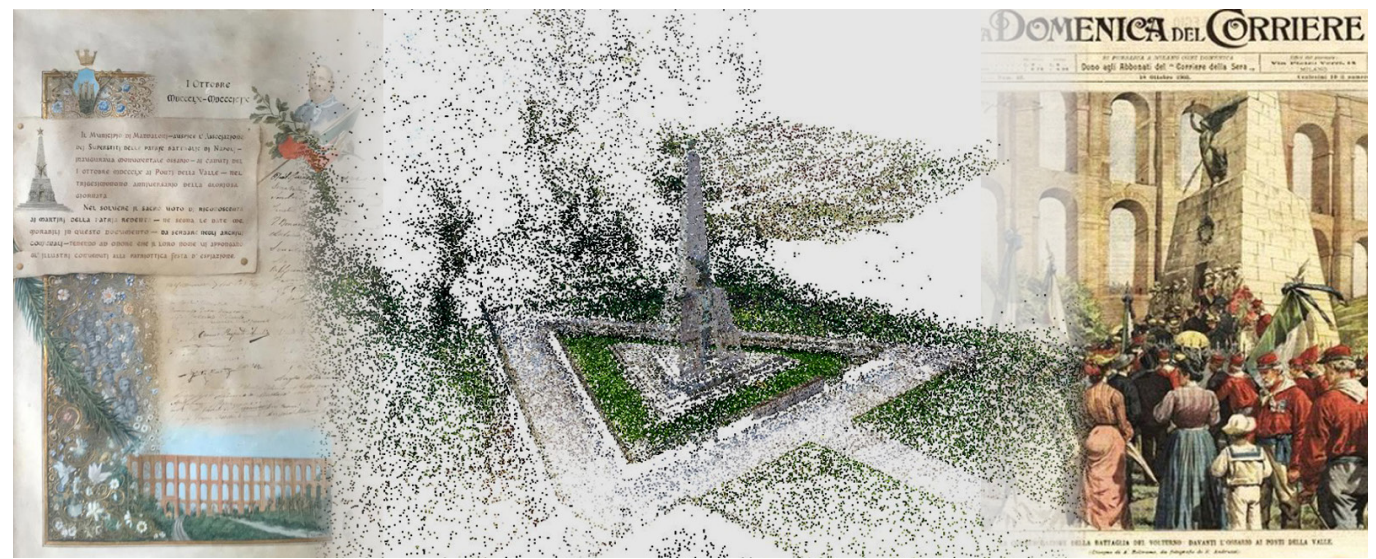




\section{The story of the built through unpublished documentary research}

Every place of memory is the product of events that see it involved during the time. That's why, it is almost certain that only one place in memory welcomes one or more stories, that are often in contrast each other, just like the Ponti della Valle. In fact, they were born from the dream of magnificence of a king and became a symbol of the power of a dynasty and then became the theater of the defeat of the same dynasty a hundred years later. On October I, I 860 the decisive clash of the field battle took place at the Carolino aqueduct; this battle, none as the battle of the Volturno, is considered the symbol of all Risorgimento, by most people. However, the Volturno river was not the protagonist of the events which took place in the Caserta hinterland, that is among the territories of Santa Maria Capua Vetere, Sant'Angelo and the slopes of the Tifatini mountains.

Between the territories of Maddaloni and Valle di Maddaloni the two opponents were lined up: the Garibaldian troops of Bixio, who established his headquarters in Villa Gualtieri, and the Bourbon brigades of General Von Meckel, who broke away, before the dawn of I October 1860, from those of General Ruiz with whom they stayed near Limatola. After a lot of attacks and clashes the Garibaldians provoked the retreat of the Bourbon troops and the consequent discouragement of the same which determined the final surrender and the definitive victory of the general Garibaldi.

The historical events provoked a new society organization, to the point that the people themselves, previously largely in favor of the Bourbon sovereigns, asked to organize events in favor of the memory of the battle and to place warnings. The president of the Association of Survivors of the homelands of Naples battles, Vincenzo Migliorini, had the idea to build a monument to the Ponti della Valle that would collect the bones of the fallen on October I, 1860. So he transmitted a written note, dated 7 September 1887, to the mayor of Maddaloni Giuseppe Tammaro, who accepted the idea monument and granted the active patronage of the municipality and in a short time a promoting committee was set up for the building of the monument. One of the different tasks of the committee was the raising of the funds needed for the implementation. Money arrived from municipal administrations, private people and His majesty the king in a short time.

The archival studies gave only written documents, which narrate the project of the monument and its possible variations, but they don't show graphic documents. The document [I], dated May 25, 1888, reports that the project was signed by Eng. cav. Carmelo Destino and the sculptor prof. Enrico Mossuti and this passage "the monument will rise on the slopes to the right of the Ponti della Valle coming from Maddaloni". Furthermore, it "will have a travertine stone base on stairs [...]. The main figures of the Garibaldians will be carved in great relief in the basement of the travertine stone. It will be surmounted by a group of three inverted bronzed faci tied by oak branches and ribbons. These faci in turn will be surmounted
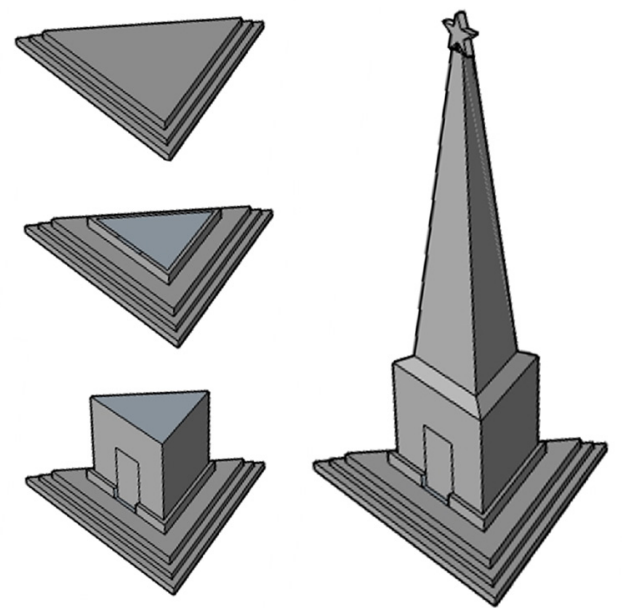
by the shiny metal star of Italy. Around the steps there will be scattered scraps of arms [...]. The part of the basement has a frieze in the front [...] which gives access to the interior, which will be the ossuary. The whole monument will feature a triangular pyramid placed on three stairways. Once the work is completed, it is necessary to surround the monument with tall trees to limit the horizon".

The document refers to a sketch, which should also have reported the dimensions of the individual elements. The sketch is not present in the archives, however, it was possible to know the measures of the aforementioned elements in based of the description "the first staircase m. 10.10 on each side; The second one m. 3.50; the third m. 8.90 and each with a height of $0.33 \mathrm{~m}$. and for 0.30 of tread [...]. On the mentioned baseboard there is the pyramid trunk of width for each side of m.5.50 in base and m. 3.70 on top. The height is m. $4.50[\ldots]$ The pyramid is surmounted by the three faci that are surmounted by the star of Italy, with an overall height of m. I I.00".

In addition, the expenditure necessary for the execution of the monument was estimated at about fifteen thousand lire. From public writing [2] it is clear that "the mentioned gentlemen [...] agreed to carry out the project under the direction of the engineer Cav. Carmelo Destino". It was established that "the monument was to be build and completed by the month of September of the following year |89|". Due to various difficulties that followed, it was not possible to complete the work, so "now having to complete the work Mossuti has the annuity of the committee, entrusted to Mr. Giuseppe Cozzolino to carry out the work in masonry and limestone".

The most important reasons that led to the delay of the work were the purchase and sale of the state property on which to erect the monument [3], which took place on II August 1899, and changes to the project with works not considered in the initial estimate. Some change were: excavation and transportation of unusable land; foundation to reach $8.50 \mathrm{~m}$. and the choice of making the brick arched crypt. In conclusion, in the document 6 - 224 it is written that "the Engineer Director and test engineer, having examined the Monument [...] certifies that the works are not only testable, but also under any commendable relationship, having been carried out with great diligence and contractual conditions" [4]. So on I October 1899, on the anniversary of the battle, the Garibaldian Monument was inaugurated with a significant parade.

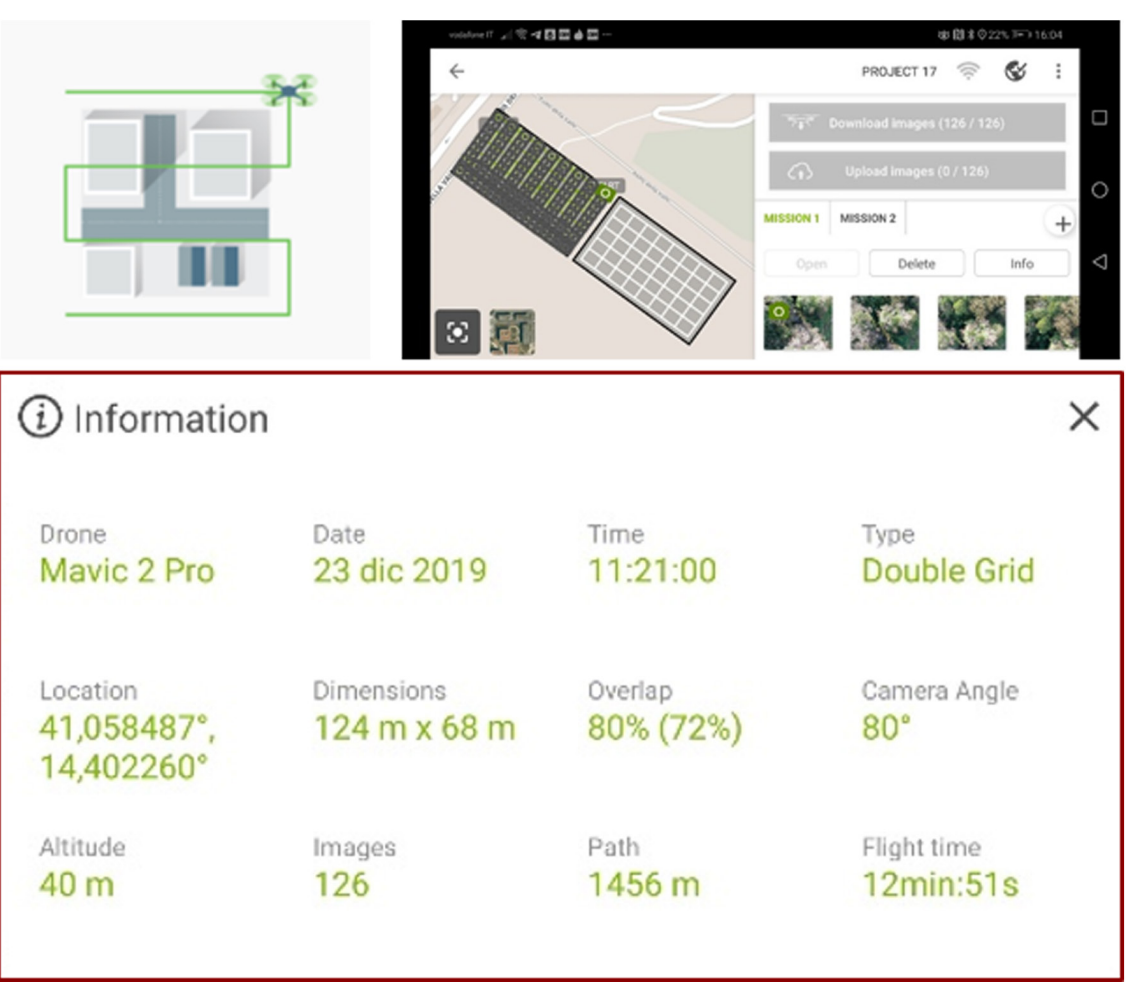




\section{Knowledge through the use of the digital model}

Different methods in research have been to define the various operational phases in order to create three-dimensional digital models aimed at the documentation, use and communication of the Garibaldian monument. We can put in evidence that the historical documentary research activities, carried out at various structures (Superintendence Library, Caserta office, Caserta State Archive, Maddaloni City Library, Maddaloni Civic Museum Library), have been of fundamental importance in order to document its evolution. In fact, this type of activity has become a cognitive process which, through the complex activities of surveying, becomes an instrument of knowledge for the documentation, enhancement and determination of modern communication methods.

The main phases of this study are divided into:

- research for document archive, which determined the knowledge and the transformations through which it was possible to reconstruct the history, backwards, of the monument;

- recording of metric and architectural data, which helped to determine a direct knowledge of the monument. The information, derived from the detection phases, have been obtained by using of no-contact technologies, with passive optical sensors based on the acquisition of images;

- data processing with determination of a representative model the state of the places and of a model which reproduces the original configuration of the monument;

- finally, choice of communication systems aimed at knowledge, enhancement and dissemination of the site.

The articulation of the monument, also linked to the conformation of the site, determined an acquisition campaign based on a detailed investigation project, in order to be able to choose the best solutions in terms of techniques and phases of metric data acquisition.

Therefore, non-invasive and no-contact technologies were used for the acquisition of metric and colorimetric data. The decision to carry out an integrated digital survey took the form of a multi-resolution approach in order to recording photographic data sets, with terrestrial and avioriprese acquisitions and subsequent processing based on photogrammetric algorithms.

The photographic data sets from avioriprese were recorded with drone brand DII, model Mavic 2 Pro, with the acquisition of about two hundred images. The images were acquired with prior flight planning in order to guarantee the all coverage of the monument, part of the external area and minimize the noise.
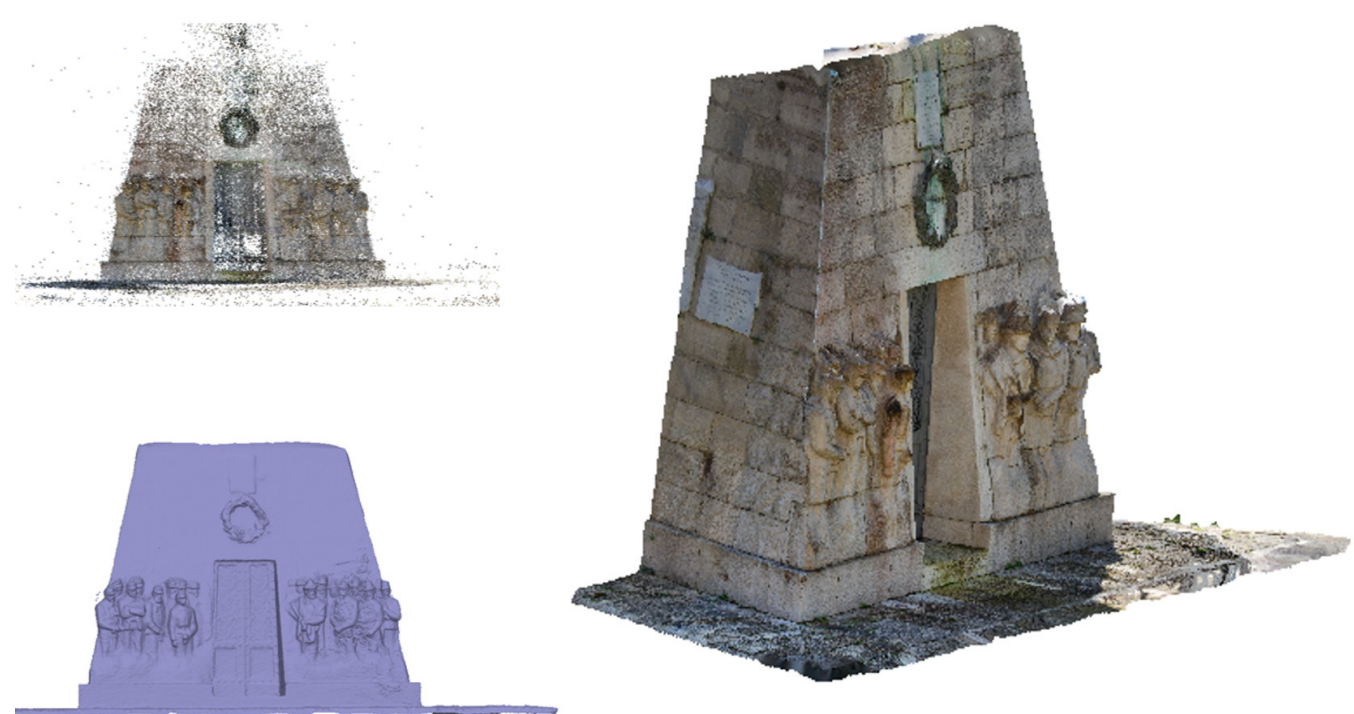
The monument was investigated according to three flight modes:

- double grid, with acquisition area of about $124 \mathrm{~m} \times 68 \mathrm{~m}$, double orthogonal flight grid, $80 \%$ overlap, camera inclined at $80^{\circ}$, flight altitude $40 \mathrm{~m}$, total frames 126, flight path $1456 \mathrm{~m}$ and flight time equal $12 \mathrm{~min} .5 \mathrm{Isec}$.;

- circular, with acquisition area of about $25 \mathrm{~m} \times 25 \mathrm{~m}$, circular flight, acquisition of frames every $10^{\circ}$, flight altitude $18 \mathrm{~m}$, total frames 36 , flight path $49 \mathrm{~m}$ and flight time equal to $2 \mathrm{~min}$. I 0 sec. - freeflight, acquisition of the frames with drone in a position parallel to the main facade of the monument and shooting according to vertical streaks, total frames 48 , flight path $40 \mathrm{~m}$ and flight time equal to $6 \mathrm{~min}$. $37 \mathrm{sec}$.

The camera used, standard on the Mavic 2 Pro, is an integrated Hasselblad, equipped with a I-inch size CMOS sensor, 20-megapixel resolution and I0-bit color depth. The camera is equipped with the HNCS system, that is Hasselblad Natural Color Solution, which offers the best possible natural colors. HNCS offers smoother tonal transitions and a film-like image quality, thanks to its 16-bit color depth, if it is compared to smaller DSLR sensors.

The planning and management of the flight plan was carried out with the Pix4Dcapture App installed on a mobile device connected to the remote control. By choosing the different schedules, among those present within the application, it was possible to set the different parameters related to the quality and precision of the model to be processed. The setting of the mapping parameters affected the overlapping of the images, the angle of the camera and the flight altitude according to the needs of the site. It was possible to monitor the flight mission, in real time, by using the map and camera view. Similarly, Mapview also provided telemetry data, returning information related to flight altitude and flight speed.

All the acquired images were checked on site directly within the app in order to avoid rework. Instead, the photographic data sets with terrestrial shooting were acquired with a reflex type camera, Nikon brand, model D40, with the acquisition of about three hundred images. The terrestrial survey had the purpose of deepening and integrating the part of the bas-reliefs, that was already obtained from the avioriprese. It was used is a DSLR camera with APS-C sensor with dimensions of $23.5 \times 15.7 \mathrm{~mm}, 6.0$ megapixels resolution and frame recording with lens fixed at $18 \mathrm{~mm}$, using AF-S DX NIKKOR $18-55 \mathrm{~mm}$ lens. The photographic data sets were acquired in full respect of the overlapping of the images, approximately $80 \%$, by integrating parallel axis shots and convergent axis shots based on the needs of the site.

The processing of all photographic data sets, organized by type of acquisition, was carried out using the Agisoft Metashape software, based on by using of algorithms for the automatic

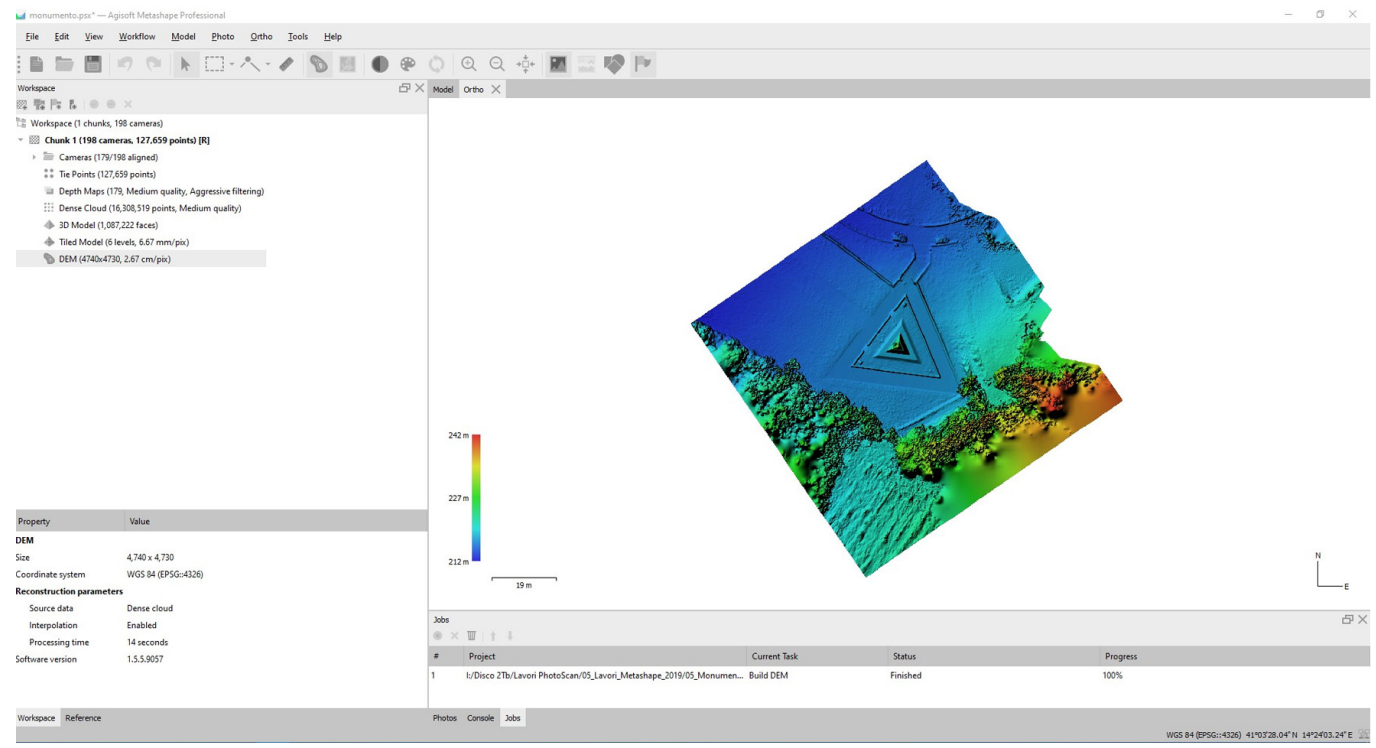


orientation of the frames. The cloud of points obtained from the photographic datasets allowed to define the model appropriately scaled thanks for the metric data recorded on the site. In order to elaborate the acquisition data two chunks were realized within the program and they were subsequently merged into a single representative model of the monument. The different phases of acquisition of photographic and metric data have allowed to generate three-dimensional models with subsequent extrapolation and determination of planar images and / or elevations by allowing the texturing process of the models.

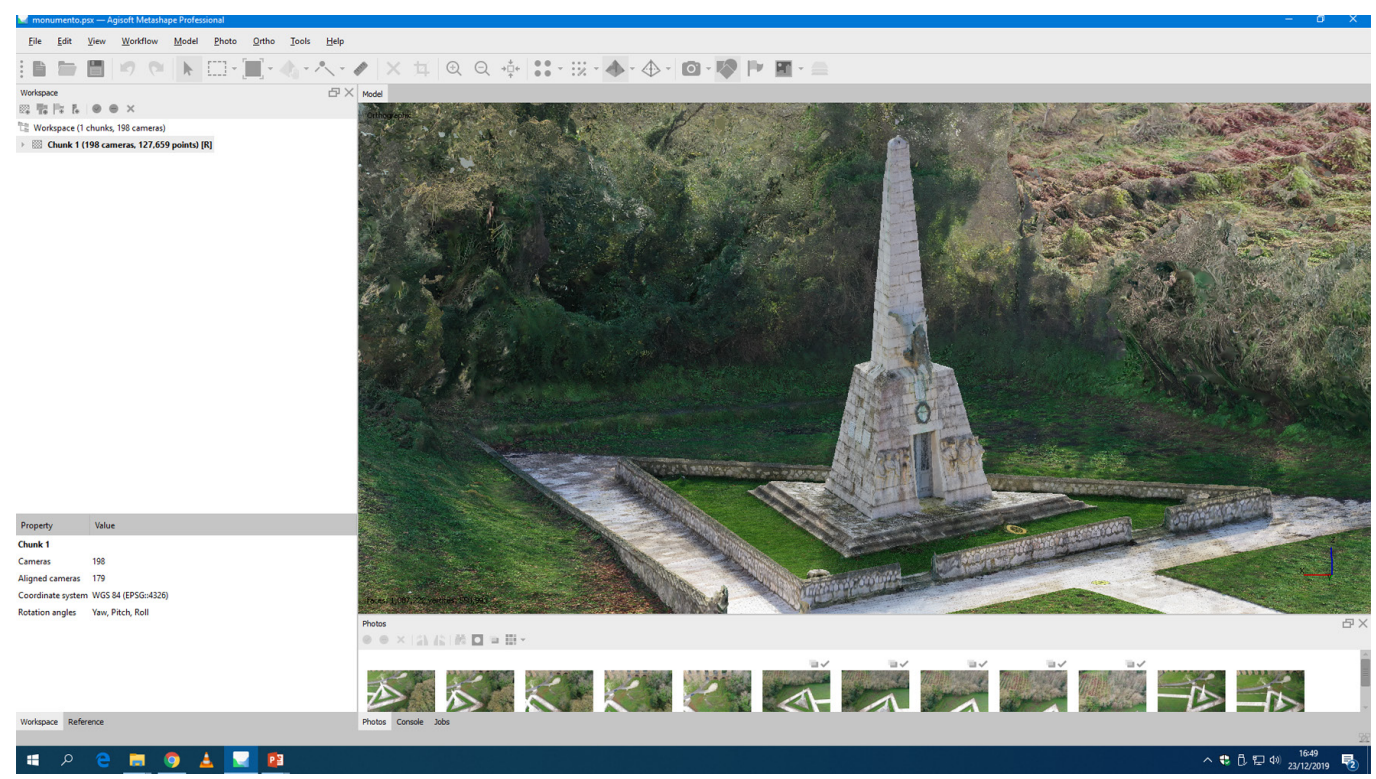

\section{Applications and conclusions}

The generation of photorealistic three-dimensional models was followed by the enhancement and dissemination of the monument through modern communication methods. The possibility of being able to bring a camera to altitude, thanks to the drone, has made it possible to better capture, in the most disparate conditions, various photographic images, that were used later to process equirectangular images. The recording of the frames was carried out with the DJI Go 4 App installed on a mobile device connected to the remote control. The monument was photographed according to the method of acquisition: Pano DJl, by means of which it is possible to create a sequence of wide-angle shots that the application automatically combines and transforms into a single panoramic image with a wide shot. In this specific case, two flights were carried out for a total of 52 frames acquired, with a fixed trigger point at $30 \mathrm{~m}$ and $50 \mathrm{~m}$. The generation of equirectangular images, loaded on special viewing platforms, offers users a more realistic use of the monument. The virtual tour is a tool used also and above all for promotion on the web, the particular display and navigation mode, combined with points of interest, allows you to investigate, in the round, the existing heritage.

In conclusion, the multidisciplinary approach with which the case study was investigated allowed to return in "its entirety" the existing construction of a historical artifact of which there were neither representations and nor correct and valid enhancement. The objective is to continue the work of documentation and representation that has begun to spread knowledge of the site, including modern communication methods. 


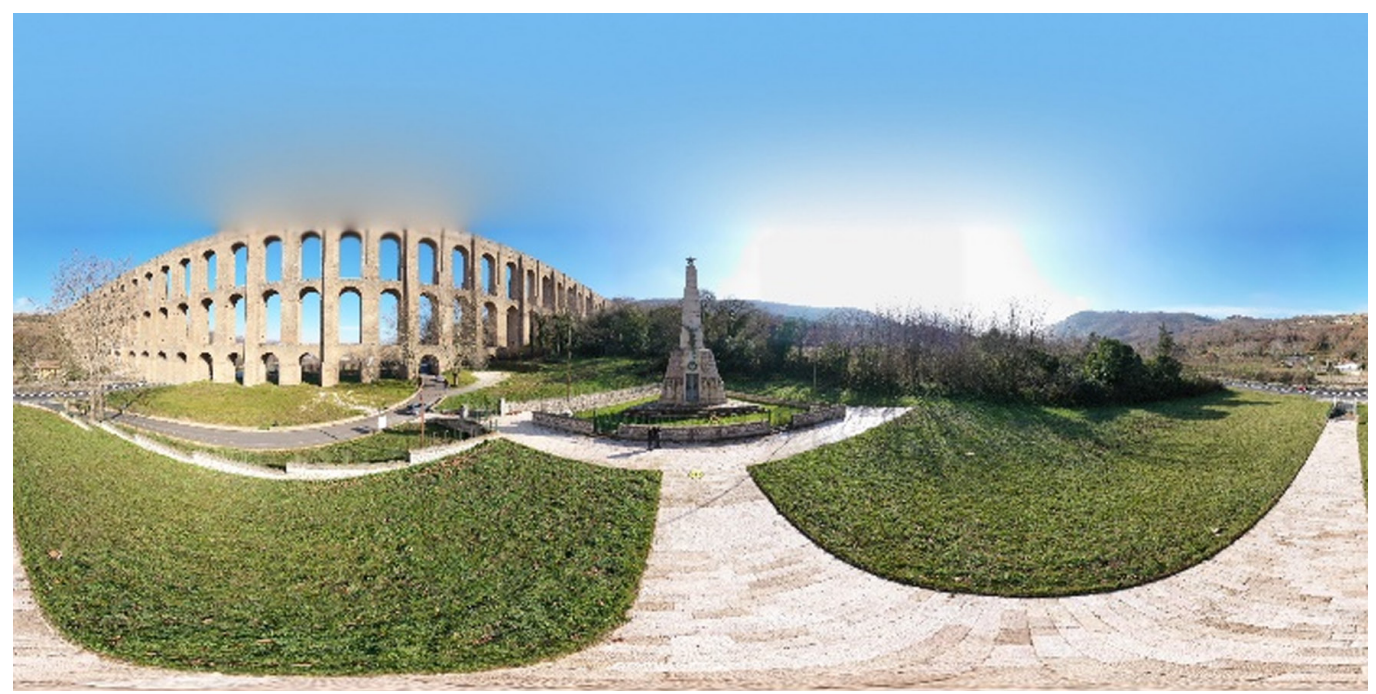

Fig. 7. Equirectangular image - altitude $50 \mathrm{~m}$.

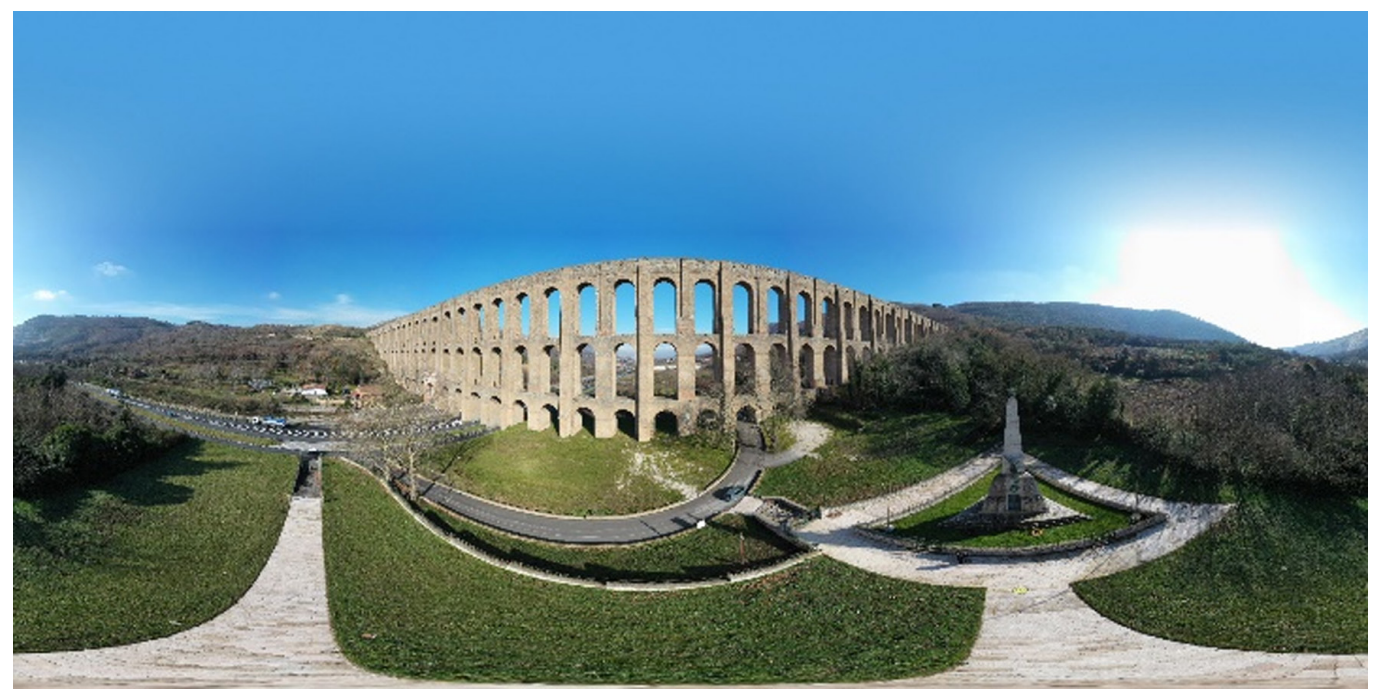


Fig. 8. Virtual Tour: $<$ https://poly.google.com/u/0/ view/eMKI2oWEu8>.

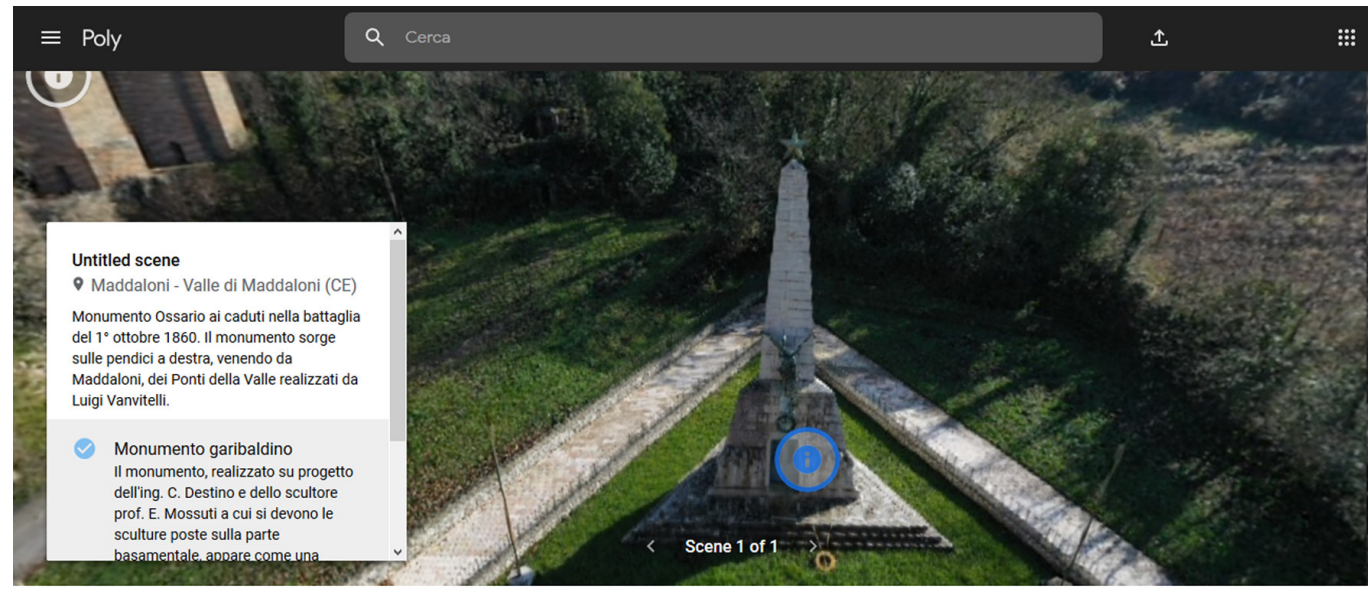

Monumento garibaldino 1 visualizzazione

\section{Notes}

[I] Signed by the mayor of Maddaloni G. Tammaro, Maddaloni Municipal Library Archive.

[2] Writing reg. in Maddaloni on Ist October seg. at N. I 39, Maddaloni Municipal Library Archive.

[3] Private writing to be enforced as a public act, reg. in Maddaloni at Mod. 2,Vol. 19 fl. I 72, Archive Municipal Library Maddaloni.

[4] Public Writing, Maddaloni Municipal Library Archive.

\section{References}

Boriani Lucia, Guidi Maurizio, Toniolo Lucia (2015). Built Heritage: Monitoring Conservation Management. Milano: Springer International Publishing

De Luca Livio (20 I I). La fotomodellazione architettonica. Palermo: Dario Flaccovio Editore, pp 19-29.

Del Pizzo Silvo,Troisi Salvatore (20 I I). Automatic orientation of image sequences in cultural heritage. In ISPRS Ann. Photogramm. Remote Sens. Spatial Inf. Sci., 20 I I, XXXVIII-5/WI 6, pp. 293-300.

Di Lorenzo Giulio (20 I I). Nuove fonti sulla Battaglia del Volturno: elenco delle proposte che si sottomettono all'approvazione del dittatore. In Terra di Lavoro, I-2, 201 I, pp. 74-81.

Menna Fabio, Erica Nocerino, Remondino Fabio, Saleri Lunazzi Renato (20I3). Accuracy and block deformation analysis in automatic UAV and terrestrial photogrammetry - Lesson learnt. In ISPRS Ann. Photogramm. Remote Sens. Spatial Inf. Sci., 20 I3, II-5/WI, pp. 203-208.

Orlandi Marco, Vazzana Antonino, Zambruno Simone (2014). Tecnologia, Beni Culturali e Turismo: i TourVirtuali (Virtual Tours) come strumento per una corretta comunicazione dei Beni Culturali. In Storia e Futuro, 34, 2014.

Orlandi Marco, Vazzana Antonino, Zaccarini Matteo, Zambruno Simone (2013). Photographing the past: using cloud computing and photo-modelling for 3D historical architecture modelling. In Boriani Maurizio, Gabaglio Rossana, Gulotta Davide. Built Heritage 201 3: Monitoring Conservation Management. Milano: Politecnico di Milano, Centro per la Conservazione e Valorizzazione dei Beni Culturali

Pepe Massimiliano, Prezioso Giuseppina (2016). Two Approaches for Dense DSM Generation from Aerial Digital Oblique Camera System. In Proceedings of the 2nd International Conference on Geographical Information Systems Theory, Applications and Management, II, 2016, 10, pp. 63-70

Remondino Fabio (20 I I). Rilievo e modellazione 3D di siti e architetture complesse. In Disegnarecon, 8/20 I I, 4, pp. 90-98.

\section{Authors}

Domenico lovane, Università degli Studi di Napoli Federico II, domenico.iovane@unina.it

Rosina laderosa, Università degli Studi di Napoli Federico II, rosina.iaderosa92@gmail.com

To cite this chapter. lovane Domenico, laderosa Rosina (2020). La rappresentazione digitale per la documentazione e l'investigazione: il caso studio del monumento garibaldino ai Ponti della Valle/The digital representation for documentation and investigation: the case study of the Garibaldi monument at the Ponti della Valle. In Arena A., Arena M., Brandolino R.G., Colistra D., Ginex G., Mediati D., Nucifora S., Raffa P. (a cura di). Connettere. Un disegno per annodare e tessere. Atti del $42^{\circ}$ Convegno Internazionale dei Docenti delle Discipline della Rappresentazionel Connecting. Drawing for weaving relationships. Proceedings of the 42th International Conference of Representation Disciplines Teachers. Milano: FrancoAngeli, pp. 2328-2343. 